\title{
A Strong Promoter Fragment from the Large Noncoding Region of Soybean Chlorotic Mottle Virus DNA
}

\author{
Luis R. CONCI*, Yoko NishizaWA**, Miho SaITO***, \\ Tomoko DATE***, Akira HaSEgaWA***, Keizaburo MIKI ${ }^{* * *}$ \\ and Tadaaki HIBI ${ }^{* *}$
}

Key words : strong promoter, noncoding region, SoyCMV DNA, transient expression assay, electroporation, tobacco protoplast.

Soybean chlorotic mottle virus (SoyCMV) is a member of the caulimovirus group of plant viruses and infects only four species of legume plants ${ }^{13}$. The double-stranded DNA genome of SoyCMV (8,175 bps) contains nine open reading frames (ORFs) and one large noncoding region ${ }^{12)}$. We previously reported that a promoter fragment (P IV) from the upstream of SoyCMV putative coat protein gene exhibited a comparable activity to the cauliflower mosaic virus (CaMV) $35 \mathrm{~S}$ promoter ${ }^{12}$. In the present paper, we show that another promoter fragment (P NCR) from the large noncoding region of SoyCMV genome caused approx. five-fold stronger expression activity than the CaMV $35 \mathrm{~S}$ promoter. We also show that truncation of P IV fragment remarkably reduced the promoter activity. The relationships between structure and activity of P NCR and P IV are discussed, with comparison to those of CaMV $35 \mathrm{~S}$ promoter ${ }^{3,17-19)}$ and figwort mosaic virus (FMV) $34 \mathrm{~S}$ promoter ${ }^{23}$.

Three kinds of SoyCMV promoter fragments were prepared as follows. The P NCR promoter fragment of $486 \mathrm{bp}$ from the large noncoding region was obtained by polymerase chain reaction (PCR) using two oligonucleotide primers: $5^{\prime}$-CCAAGCTTATGTAGGACATGCCAGCTGTAA- $3^{\prime}$ and $5^{\prime}$ CCGGATCCTTTCTTTTCTCTTGTGCTTG-3', and pSSac as template DNA. These two primers corresponded to the start position (nucleotide no. 5979-6000) and near the end position (nucleotide no. 6443-6464) of the SoyCMV large noncoding region (nucleotide no. 5979-6474) and had additional HindIII and Bam HI sites for cloning. pSSac was a full-length SoyCMV DNA clone ligated with pUC18 $8^{24}$. Amplification was done using a GeneAmp PCR Reagent kit (Perkin Elmer Cetus) in $50 \mu 1$ of $10 \mathrm{mM}$ Tris- $\mathrm{HCl}$ ( $\mathrm{pH} 8.3$ ), $50 \mathrm{mM} \mathrm{KCl}, 1.5 \mathrm{mM} \mathrm{MgCl}_{2}, 0.01 \%$ (w/v) gelatin, each $200 \mu \mathrm{M}$ dNTPs, each $1 \mu \mathrm{M}$ primers, $1 \mathrm{ng}$ template DNA and 5 units of AmpliTaq DNA polymerase. Thermal cyclings were carried out 30 cycles of $94^{\circ} \mathrm{C}$ for $1 \mathrm{~min}, 55^{\circ} \mathrm{C}$ for $2 \mathrm{~min}$ and $72^{\circ} \mathrm{C}$ for $3 \mathrm{~min}$ by an ATTO Zymoreactor.

The P IV promoter fragment of 378 bp (nucleotide no. 689-1066) from the upstream of SoyCMV putative coat protein gene (ORF IV) was excised from ORF III (nucleotide no. 647-1223) as a HindIII$X b a$ I fragment as described previously ${ }^{12)}$.

The truncated promoter fragment of P IV (P $\Delta \mathrm{IV}$ : nucleotide no. 689-981), lacking 85 bp of $3^{\prime}$-terminal region of $\mathrm{P}$ IV, was prepared as follows. A SspI site was introduced at nucleotide no. 978$983\left(5^{\prime}\right.$-AATATC- $\left.3^{\prime}\right)$ by converting the sequence into $5^{\prime}$-AATATT $-3^{\prime}$ using oligonucleotide-mediated site-directed mutagenesis ${ }^{22)}$ and the $\mathrm{P} \Delta \mathrm{IV}$ fragment of $293 \mathrm{bp}$ was excised from this mutated DNA clone as a HindIII-SspI fragment.

The promoter fragments, P NCR, P IV and P $\Delta I V$, were inserted $5^{\prime}$-proximal to the $\beta$-glucuronidase (GUS) gene of pBI 221 (Clontech Laboratories) ${ }^{14}$, from which the CaMV 35S promoter fragment (P 35S)

* National Institute of Agricultural Technology, Arturo M. Bas 276, 5000 Cordoba, Argentina

** Laboratory of Applied Microbiology, National Institute of Agrobiological Resources. Tsukuba, Ibaraki 305, Japan 農業生物資源研究所

*** Fundamental Research Laboratory, TONEN Co., Nishi-tsurugaoka, Ohi-machi, Iruma-gun, Saitama 354, Japan トーネン基硞研究所 
had been removed previously by double digestion with HindIII and Bam HI (for P NCR), HindIII and $X b a I$ (for P IV) or HindIII and Sma I (for P $\Delta I V$ ). The resulting chimeric plasmids were named P NCR/ GUS/pUC19, P IV/GUS/pUC19 and P $\Delta$ IV/GUS/pUC19, respectively. pBI 221 is called here P 35S/ GUS/pUC19 for convenience, and was also used for comparison. The CaMV $35 \mathrm{~S}$ promoter fragment in pBI 221 has approx. $800 \mathrm{bp}$ length, of which the $3^{\prime}$-end is an original DdeI site of nucleotide no. 7575 of $\mathrm{CaMV}^{11,24)}$.

Electroporation of tobacco mesophyll protoplasts (Nicotiana tabacum L. cv. Xanthi NN) was carried out according to the procedures described previously ${ }^{12}$, with the following modifications. The protoplasts were suspended at approx. $2.5 \times 10^{5} / \mathrm{ml}$ in $0.5 \mathrm{M}$ mannitol with $100 \mu \mathrm{M} \mathrm{MgCl}_{2}$ and mixed with the chimeric plasmids at $50 \mu \mathrm{g} / \mathrm{ml}$ and carrier salmon sperm DNA at $40 \mu \mathrm{g} / \mathrm{ml}$ at $4^{\circ} \mathrm{C}$. The protoplast suspension was exposed at $4^{\circ} \mathrm{C}$ to five square $\mathrm{DC}$ pulses of $50 \mu \mathrm{s}$ duration at $800 \mathrm{~V} / \mathrm{cm}$ in the electric field by a JASCO CET-200 continuous-flow electro-manipulator. The electroporated protoplasts were incubated for $40 \mathrm{hr}$ at $25^{\circ} \mathrm{C}$ under approx. 1,000 lux continuous illumination. After incubation the protoplasts were collected by centrifugation at $600 \mathrm{rpm}$ for $5 \mathrm{~min}$, lysed with a Vortex mixer and prepared according to the modified procedures ${ }^{16}$ for the fluorometric GUS assay ${ }^{14}$. An aliquot of the samples was taken for the protein assay using a Bio-Rad protein assay kit. GUS activity was measured using a JASCO FP-777 spectrofluorometer at $365 \mathrm{~nm}$ for excitation (band width : $10 \mathrm{~nm}$ ) and $455 \mathrm{~nm}$ for emission (band width: $5 \mathrm{~nm}$ ). Protein content was measured using a Bio-Rad 450 microplate reader at $595 \mathrm{~nm}$.

Figure 1 shows the results of expression activities for the four promoter fragments in electroporated tobacco mesophyll protoplasts after $40 \mathrm{hr}$ of incubation as determined by transient GUS assay. SoyCMV P NCR fragment exhibited approx. five-fold stronger activity compared to CaMV 35S promoter fragment. SoyCMV P IV fragment showed a comparable activity to the CaMV 35 S promoter fragment, as already reported ${ }^{12)}$. P $\Delta I V$ fragment exhibited only approx. one fourth activity of P IV.

The nucleotide sequences of CaMV $35 S^{6)}$, FMV $34 \mathrm{~S}^{21}$, SoyCMV P NCR and SoyCMV P IV ${ }^{12}$ promoter fragments are compared in Fig. 2. SoyCMV P NCR and P IV fragments have shorter upstream regions before the TATA box (approx. $170 \mathrm{bp}$ and $230 \mathrm{bp}$, respectively) and the P NCR fragment has a

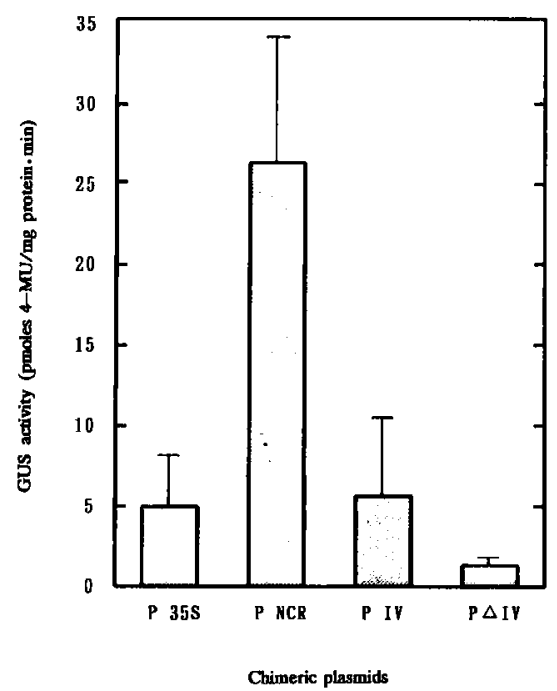

Fig. 1. GUS activities caused by four different promoter fragments in electroporated tobacco mesophyll protoplasts as determined by transient expression assay. Means and standard deviations from six independent experiments are shown. P 35S : P 35S/GUS/pUC19 chimeric plasmid, P NCR : P NCR/ GUS/pUC19 chimeric plasmid, P IV: P IV/GUS/pUC19 chimeric plasmid, P $\Delta I V: P \Delta I V / G U S / p U C 19$ chimeric plasmid. 


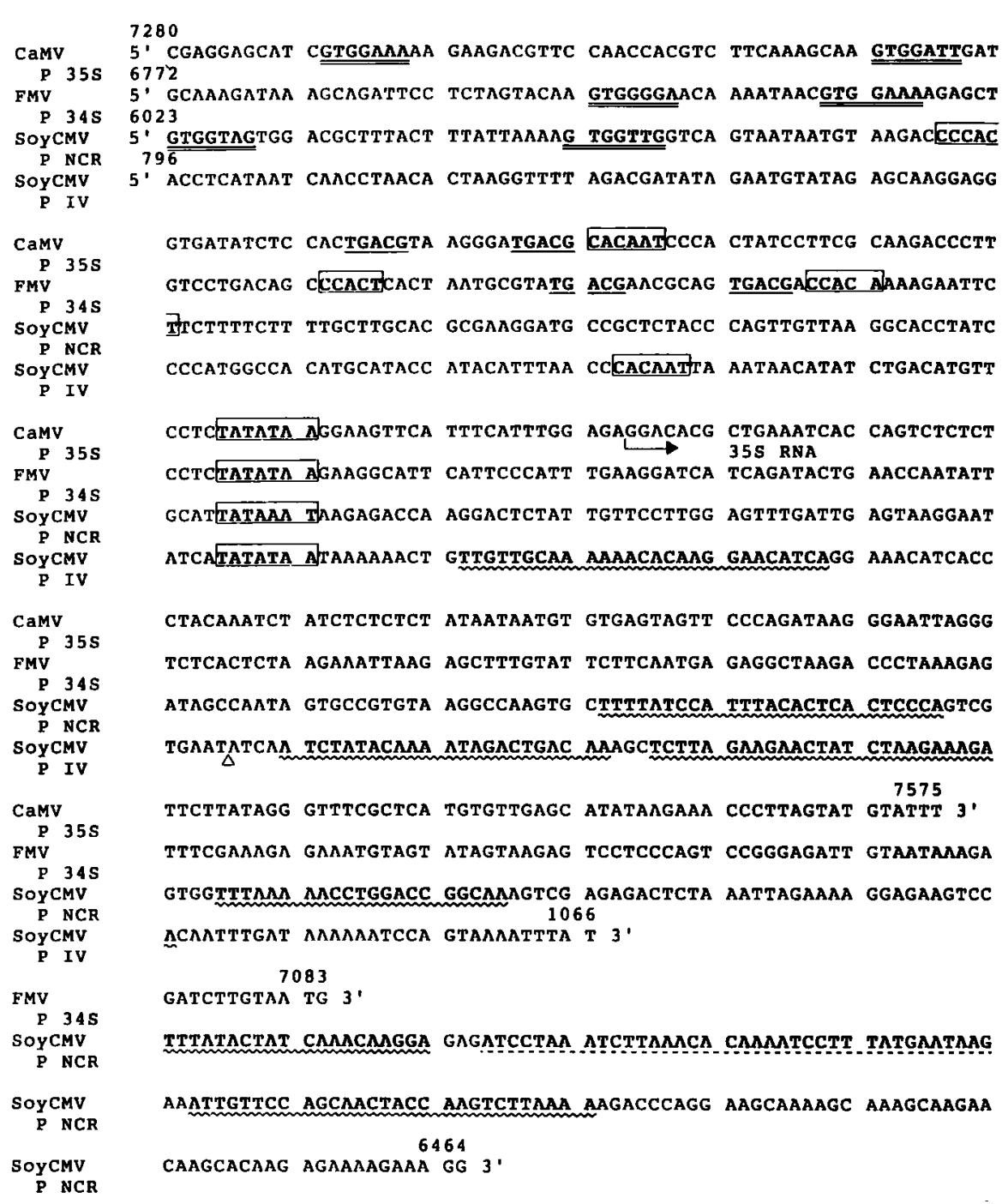

Fig. 2. Comparative nucleotide sequences in the promoter fragment of CaMV 35S. FMV 34S, SoyCMV P NCR and SoyCMV P IV. box: CAAT and TATA boxes, double underline: GT motifs, single underline : TGACG motifs, dotted underline : bowl sequence, wavy underline : translational enhancer core-like sequences triangle: $\mathrm{P} \Delta \mathrm{IV}$ lacks a $3^{\prime}$ 'terminal region here after.

longer downstream region after the TATA box (approx. $310 \mathrm{bp}$ ) than CaMV 35S and FMV 34S promoter fragments. The $34 \mathrm{~S}$ promoter fragment of FMV, one of caulimoviruses, has been reported to have an approx. $63 \%$ homologous sequence to CaMV $35 \mathrm{~S}$ promoter core (around the TATA box) and a comparable activity to that of CaMV $35 \mathrm{~S}$ promoter fragment in protoplast transient expression assay $^{23)}$. Both CaMV 35S and FMV 34S promoter fragments have more than two GT motifs (SV 40 transcriptional enhancer core-like sequence) ${ }^{5,17,19)}$, two TGACG motifs (histone gene transcriptional regulation motif) ${ }^{2,5,23)}$, CAAT-like boxes and TATA boxes ${ }^{17,21,23)}$.

The SoyCMV P NCR fragment also contained two GT motifs, CAAT-like and TATA boxes but no 
TGACG motif. SoyCMV P IV fragment had also CAAT and TATA boxes but no GT or TGACG motifs, as described previously ${ }^{12)}$.

Although the sequence homology between SoyCMV P NCR and CaMV 35 S promoter is lower than that between FMV 34S and CaMV 35 S promoter and the transcripts of SoyCMV have not yet been analysed, SoyCMV P NCR is assumed to be a promoter corresponding to the CaMV $35 \mathrm{~S}$ promoter. This is based on its location in the viral genome and its fundamental structural similarity to CaMV $35 \mathrm{~S}$ promoter, including the existence of a bowl sequence as discussed previously ${ }^{12}$. Bowl sequences were reported to be present also in the downstream of large noncoding regions of three other caulimoviruses and not to affect transient gene expression in electroporated protoplasts ${ }^{7}$.

SoyCMV P IV is assumed to be a promoter for the coat protein gene ${ }^{12}$.

In addition to the above-mentioned sequences, SoyCMV P NCR fragment contained four characteristic sequences (at approx. 80, 110, 170 and 220 nucleotide downstream of the TATA box) which, at the RNA level, had more than $60 \%$ of homology with the $5^{\prime}$-terminal region of tobacco mosaic virus (TMV) $\Omega$ sequence (Figs. 2 and 3). Three similar sequences were located at approx. 15, 60 and 85 nucleotide downstream of the TATA box in the SoyCMV promoter IV fragment ${ }^{12}$, but were absent in CaMV $35 \mathrm{~S}$ and FMV 34S promoter fragments. The SoyCMV P $\Delta \mathrm{IV}$ fragment lacked $85 \mathrm{bp}$ of 3 -terminal region of $\mathrm{P} I V$ containing the latter two sequences of the three. The transcription starting sites in these SoyCMV promoter fragments have not yet been shown. But, considering from the corresponding position of CaMV $35 S$ promoter, the all $\Omega$-like sequences of SoyCMV promoter fragments are assumed to be

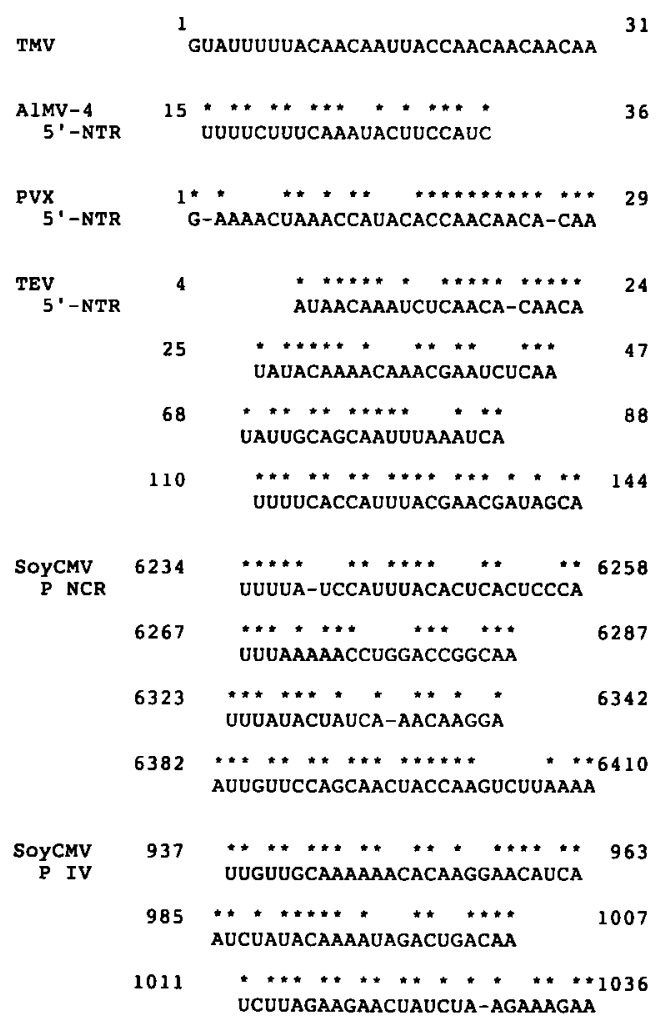

Fig. 3. Homologous regions in the $5^{\prime}$-nontranslated leader sequences of TMV, AlMV-4, PVX and TEV and in SoyCMV promoter fragments. $\star$ : identical to TMV $\Omega$ sequence. 
transcribed into $5^{\prime}$-nontranslated regions of mRNA (Fig. 2).

The $\Omega$ sequence is a 68 -nucleotide fragment of the nontranslated $5^{\prime}$-leader sequence of TMV-RNA, which has been reported to enhance the translation of contiguous foreign gene transcripts in electroporated tobacco protoplasts and has been named a translational enhancer ${ }^{8-10)}$. The sequence of the first half of this fragment is conserved among several TMV strains.

Similar translational enhancements have been reported also for a 36 -nucleotide fragment of $5^{\prime}$-leader sequence of alfalfa mosaic virus (AIMV) RNA $4^{15)}$, a 83-nucleotide leader sequence of potato virus X (PVX) $\mathrm{RNA}^{20)}$ and a 144-nucleotide fragment of $5^{\prime}$-nontranslated region (5'-NTR) of tobacco etch virus (TEV) $R \mathrm{RA}^{4}$. For TEV, it was reported that, when cDNA of the $5^{\prime} \cdot \mathrm{NTR}$ was ligated between $3^{\prime}$-terminal of CaMV 35S promoter fragment and $5^{\prime}$-terminal of GUS gene, $5^{\prime}$-NTR resulted in approx. Eight-fold stronger translational enhancement than a chimeric gene without $5^{\prime}$-NTR in transient expression assay in electroporated tobacco mesophyll protoplasts ${ }^{4}$. Also these AlMV ${ }^{15}$, $\mathrm{PVX}^{20)}$ and $\mathrm{TEV}^{1,4)}$ fragments have highly homologous sequences to the first half of TMV $\Omega$ sequence ${ }^{8)}$ (Fig. 3). Therefore it is possible that these highly homologous regions are translational enhancer core signals, even though they have no consensus sequence. However, some other factors, like secondary structures of the 5 -nontranslated regions may also relate to the translational enhancement. The highly homologous sequences to TMV $\Omega$ sequence are called here, for convenience, translational enhancer core-like sequences (TLEs).

The four promoter fragments used in this study contain the following numbers of GT motifs and TLEs:

$\begin{array}{lll}\text { CaMV 35S } & 3 & 0 \\ \text { SoyCMV P NCR } & 2 & 4 \\ \text { SoyCMV P IV } & 0 & 3 \\ \text { SoyCMV P DIV } & 0 & 1\end{array}$

Comparing this table with the promoter activities shown in Fig. 1, it is suggested that TLEs are present also in the promoter core-downstream regions of SoyCMV double-stranded DNA genome and that the TLEs might participate in translational enhancement after they are transcribed into $5^{\prime}$. nontranslated regions of mRNA, while the promoter core-upstream GT motifs might be involved in transcriptional enhancement ${ }^{19}$. Detailed analyses on the actual activities of the possible transcriptional and translational enhancer core-like sequences in the SoyCMV P NCR fragment are now in progress.

We would like to thank Dr. I. Havukkala of the National Institute of Agrobiological Resources for correcting the English language.

\section{Literature cited}

1. Allison, R., Johnston, R.E. and Dougherty, W.G. (1986). The nucleotide sequence of the coding region of tobacco etch virus genomic RNA: evidence for the synthesis of a single polyprotein. Virology 154: 9-20.

2. Benfey, P.N., Ren, L. and Chua N.-H. (1989). The CaMV 35 S enhancer contains at least two domains which can confer different developmental and tissue-specific expression patterns. EMBO J. 8:2195-2202.

3. Benfey, P.N. and Chua N.-H. (1990). The cauliflower mosaic virus $35 \mathrm{~S}$ promoter: combinatorial regulation of transcription in plants. Science $250: 959-966$.

4. Carrington, J.C. and Freed, D.D. (1990). Cap-independent enhancement of translation by a plant potyvirus $5^{\prime}$ non-translated region. J. Virol. 64: 1590-1597.

5. Fang, R-X., Nagy, F., Sivasubramanian, S. and Chua, N.-H. (1989). Multiple cis regulatory elements for maximal expression of the cauliflower mosaic virus $35 \mathrm{~S}$ promoter in transgenic plants. Plant Cell $1: 141-$ 150.

6. Franck, A., Guilley, H., Jonard, G., Richards, K. and Hirth, L. (1980). Nucleotide sequence of cauliflower mosaic virus DNA. Cell $21: 285-294$.

7. Futterer, J., Gordon, K., Bonneville, J.M., Sanfacon, H., Pisan, B., Penswick, J. and Hohn, T.H. (1988). The leader sequence of cauliflower large RNA can be folded into a large stem-loop structure. Nucl. Acids Res. $16: 8377-8390$. 
8. Gallie, D.R., Sleat, D.E., Watts, J.W., Turner, P.C. and Wilson, T.M.A. (1987a). The $5^{\prime}$-leader sequence of tobacco mosaic virus RNA enhances the expression of foreign gene transcripts in vitro and in vivo. Nucl. Acids Res. $15: 3257-3273$.

9. Gallie, D.R., Sleat, D.E., Watts, J.W., Turner, P.C. and Wilson, T.M.A. (1987b). A comparison of eukaryotic viral 5'-leader sequences as enhancers of mRNA expression in vivo. Nucl. Acids Res. 15: 8693-8711.

10. Gallie, D.R., Lucas, W.J. and Walbot, V. (1989). Visualizing mRNA expression in plant protoplasts : factors influencing efficient mRNA uptake and translation. Plant Cell $1: 301-311$.

11. Guilley, H., Dudley, R.K., Jonard, G., Balàzs, E. and Richards, K.E. (1982). Transcription of cauliflower mosaic virus DNA : detection of promoter sequences, and characterization of transcripts. Cell $30: 763-773$.

12. Hasegawa, A., Verver, J., Shimada, A., Saito, M., Goldbach, R., van Kammen, A., Miki, K., Kameya-Iwaki, M. and Hibi, T. (1989). The complete sequence of soybean chlorotic mottle virus DNA and the identification of a novel promoter. Nucl. Acids Res. 17: 9993-10013.

13. Hibi, T. and Kameya-Iwaki, M. (1988). Soybean chlorotic mottle virus. CMI/AAB Descriptions of Plant Viruses, no. 331.

14. Jefferson, R.A., Kavanagh, T.A. and Bevan, M.W. (1987). GUS fusions : $\beta$-glucuronidase as a sensitive and versatile gene fusion marker in higher plants. EMBO J. 6: 3901-3907.

15. Jobling, S.A. and Gehrke, L. (1987). Enhanced translation of chimaeric messenger RNAs containing plant viral untranslated leader sequence. Nature $325: 622-625$

16. Kosugi, S., Ohashi, Y., Nakajima, K. and Arai, Y. (1990). An improved assay for $\beta$-glucuronidase in transformed cells : methanol almost completely suppresses a putative endogenous $\beta$-glucuronidase activity. Plant Sci. $70: 133-140$.

17. Odell, J.T., Nagy, F. and Chua N.-H. (1985). Identification of DNA sequences required for activity of the cauliflower mosaic virus $35 \mathrm{~S}$ promoter. Nature $313: 810-812$.

18. Odell, J.T., Knowlton, S., Lin, W. and Mauvais, J. (1988). Properties of an isolated transcription stimulating sequence derived from the cauliflower mosaic virus $35 \mathrm{~S}$ promoter. Plant Mol. Biol. 10:263-272.

19. Ow, W.D., Jacobs, J.D. and Howell, S.T. (1987). Functional regions of the cauliflower mosaic virus $35 \mathrm{~S}$ RNA promoter determined by use of the firefly luciferase gene as a reporter of promoter activity. Proc. Natl. Acad. Sci. USA $84: 4870-4874$.

20. Pooggin, M.M. and Shryabin, K.G. (1992). The $5^{\prime}$-untranslated leader sequence of potato virus X RNA enhances the expression of heterologous gene in vivo. Mol. Gen. Genet. 234 : 329-331.

21. Richins, R.D., Scholthof, H.B. and Shepherd, R.J. (1987). Sequence of figwort mosaic virus DNA (caulimovirus group). Nucl. Acids Res. $15: 8451-8466$.

22. Sambrook, J., Fritsch, E.F. and Maniatis, T. (1989). Molecular Cloning: A Laboratory Manual. Cold Spring Harbor Laboratory Press, New York.

23. Sanger, M., Daubert, S. and Goodman, R.M. (1990). Characteristics of a strong promoter from figwort mosaic virus : comparison with the analogous $35 \mathrm{~S}$ promoter from cauliflower mosaic virus and the regulated mannopine synthase promoter. Plant Mol. Biol. 14: 433-443.

24. Verver, J., Schijns, P., Hibi, T. and Goldbach, R. (1987). Characterization of the genome of soybean chlorotic mottle virus. J. Gen. Virol. 68: 159-167.

\section{和 文 摘 要}

\section{L.R. Conci・西沢洋子・斎藤美保・伊達朋子・長谷川明・三木敬三郎・日比忠明：ダイズ退緑班紋ウイルスゲノムの} 非翻訳領域に存在する強力なプロモーター

ダイズ退緑斑紋ウイルス (SoyCMV) の 2 本鎖 DNA ゲノムから，非翻訳領域に存在し，TATA 配列の上流に 2 個 の GT モチーフ, 下流に 4 個の TMV- $\Omega$ 様配列を有する P NCR, 外被蛋白質遺层子上流に存在し, 3 個の $\Omega$ 様配列を

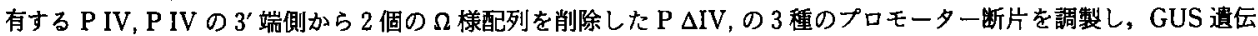
子に接続した後, タバコ葉肉プロトプラストにおける各プロモーターの発現活性を測定した。その結果, CaMV 35S プ ロモーターに比べ, それぞれ，P NCR が5.4 倍, P IV が 1.1 倍, P $\Delta \mathrm{IV} か ゙ 0.3$ 倍の活性を示し, プロモーターコア下 流に存在する $\Omega$ 様配列が, mRNA の先導配列に転写されることによって䑽訳活性を促進している可能性が示唆され た。

(Received November 9, 1992) 